\title{
Physico-chemical Characteristics of the Ecological Status of the Waters of the Ebrie Lagoon Bay (Abidjan, Côte D'Ivoire)
}

\author{
Valentin Gansso Akilinon ${ }^{1}$, Victor Kouamé Kouamé2, Bernard Ossey Yapo ${ }^{3}$ \\ ${ }^{\mathbf{1}}$ Doctoral student, Environmental Science Laboratory, Nangui Abrogoua University, Abidjan Côte d'Ivoire \\ akilinon@gmail.com
}

${ }^{2}$ Assistant professor, Lorougnon Guédé University, Daloa Côte d'Ivoire

${ }^{3}$ Professor, Environmental Science Laboratory, Nangui Abrogoua University, and Assistant Director of Ivorian Pollution Control Center , Abidjan Côte d'Ivoire

\begin{abstract}
The intensification of industrial and agricultural activities as well as the rapid increase in the population of the city of Abidjan have a negative impact on the urban waters of the Ebrie lagoon by endangering the aquatic life within its bays. To evaluate the ecological status of these bays, fifteen (15) lagoon water sampling campaigns were conducted from 2014 to 2016 on twelve (12) sites spread over nine (09) bays. The samples were subjected to physicochemical analyzes on the basis of French standards. The results obtained show that the physicochemical characteristics of bays waters are dependent on marine and continental inputs. The bays are subjected to important terrigenous and urban inputs favoring their richness in nutritive salts with rates of exceedance of the limit values recommended by Chapman and Rodier, between 20 and 100\% for nitrite, between 69 and $100 \%$ for ammonium and equal to $100 \%$ for phosphate. It appears that it is the phosphate and the ammonium which strongly degrade the ecological status and which make the waters of the bays unfit to favor an optimal aquatic life for the fauna and the flora.
\end{abstract}

Keywords: Bays, Ecological status, Ebrie Lagoon, Nutrients.

\section{Introduction}

In West Africa, the lagoons are not spared by man's relentless efforts towards development. The explosive growth of the human population has affected and gradually imposed changes in the environment and the degradation of these environments. Indeed, the geographical proximity of these lagoons to densely populated areas induces considerable exploitation of their resources, often leading to conflicts of interest. The effects of urban pollution and the contamination of the environment by waste of all kinds contribute to the destruction of habitats and have imposed serious threats and various impacts on the ecology of their resources [1]. They are thus the seat of multiple anthropic activities which are often incompatible and contradictory. In fact, the uses of lagoon environments such as aquaculture, fishing, tourism, industry, etc., are multiple and their implementation generates ecological and social conflicts in a particularly acute way in Côte d'Ivoire [2]. Previous works carried out on the Ebrie lagoon [3,4] have established direct links between the state of pollution of the lagoon and the domestic and industrial wastewater which is discharged there without any prior treatment. This has been confirmed by the work of Kouamé [5] for whom industrial effluents are not the only source of pollution of lagoon environments. Their physico-chemical quality is strongly linked to the combined influence of anthropic pressure and exchanges between oceanic and fresh waters. Other previous works [610] have shown a sharp increase in nitrogen and phosphorus compounds in the Ebrie lagoon, particularly in the bays which are therefore considered to be logically eutrophic. The present study is a continuation of these works, with the aim of analyzing the physicochemical quality of the water in lagoon bays and its impact on the ecology of these bays. Specifically, the aim is to study the spatial variations of the physicochemical and nutritional characteristics of waters; to evaluate the abundance of nutrients in the bays and to know the physicochemical quality class of each bay.

\section{Material and Methods}

a) Presentation of the study area

The area covered by this study is the estuarine zone of the Ebrie lagoon, located in the city of Abidjan in the south of Côte d'Ivoire. It is an area directly subject to oceanic influence and where the activities of the Abidjan agglomeration have the greatest impact. This study area, with an average depth of $7.5 \mathrm{~m}$, has an surface of $71 \mathrm{~km}^{2}$ with a volume of $0.54 .10^{9} \mathrm{~m}^{3}$ i.e. $20 \%$ of the total volume of the lagoon [11]. It is highly anthropized with an estimated population of 4, 395, 243 inhabitants in 2014 [12]. Indeed according to Ané [13], the estuary of the Ebrie lagoon is exposed to discharges from industrial activities present in the various communes of Abidjan that it delimits. In addition, Dufour et al. [14] point out that some of the domestic waste ends up in the lagoon by runoff or by emptying septic tanks or latrines. The estuarine area of the Ebrie lagoon is then used as a dumping ground for household waste, waste from businesses, wastewater, and septic tank discharges.

\section{b) Location of sampling sites}

Nine (09) urban bays on the Ebrie lagoon have been selected. These are Anna, Azito, Banco, Biétry (with two sites : Biétry 1 and 2), Cocody, Koumassi (with three sites: Koumassi 1, 2 and 3), M'badon, Marcory and Yopougon. 
The choice of these bays was guided by the desire to describe the influence of fresh and oceanic waters and to analyze the impact of human activities in the Abidjan area on the lagoon environment. Figure 1 shows the location of the sampling sites of lagoon water in the Abidjan agglomeration.

\section{c) Taking water samples}

The water samples were taken $0.5 \mathrm{~m}$ from the surface of the water surface using a Niskin bottle from April 2014 to October 2016. The collection, transport and storage of the samples were in accordance with the protocol defined by Afnor [15] and Rodier et al.[16]. During sampling, certain parameters such as temperature, $\mathrm{pH}$, salinity and dissolved oxygen were measured in situ using a YSI 6920 V2 multiparameter probe.

\section{d) Nutrient Analysis}

Nutrient salts $\left(\mathrm{NO}_{3}^{-}, \mathrm{NO}_{2}^{-}, \mathrm{NH}_{4}^{+}, \mathrm{PO}_{4}{ }^{3-}\right)$ were analyzed within 48 hours in the laboratory according to standardized AFNOR methods [15].

e) Physico-chemical analysis of the ecological state

The analysis was carried out using, after classifying the measurements taken over the study period, that which corresponds to $90 \%$ of the measurements for each of the parameters retained in each of the bays studied. These parameters are: dissolved oxygen $\left(\mathrm{O}_{2}\right)$, nitrate $\left(\mathrm{NO}_{3}{ }^{-}\right)$, nitrite $\left(\mathrm{NO}_{2}{ }^{-}\right)$, ammonium $\left(\mathrm{NH}_{4}{ }^{+}\right)$and orthophosphate $\left(\mathrm{PO}_{4}{ }^{3-}\right)$. The selected measure was compared to the limits of the state classes of the grid proposed by the European Framework Directive 2000/60/EC on Water (WFD) and whose form reduced to the parameters analyzed in this work is given by the table I.

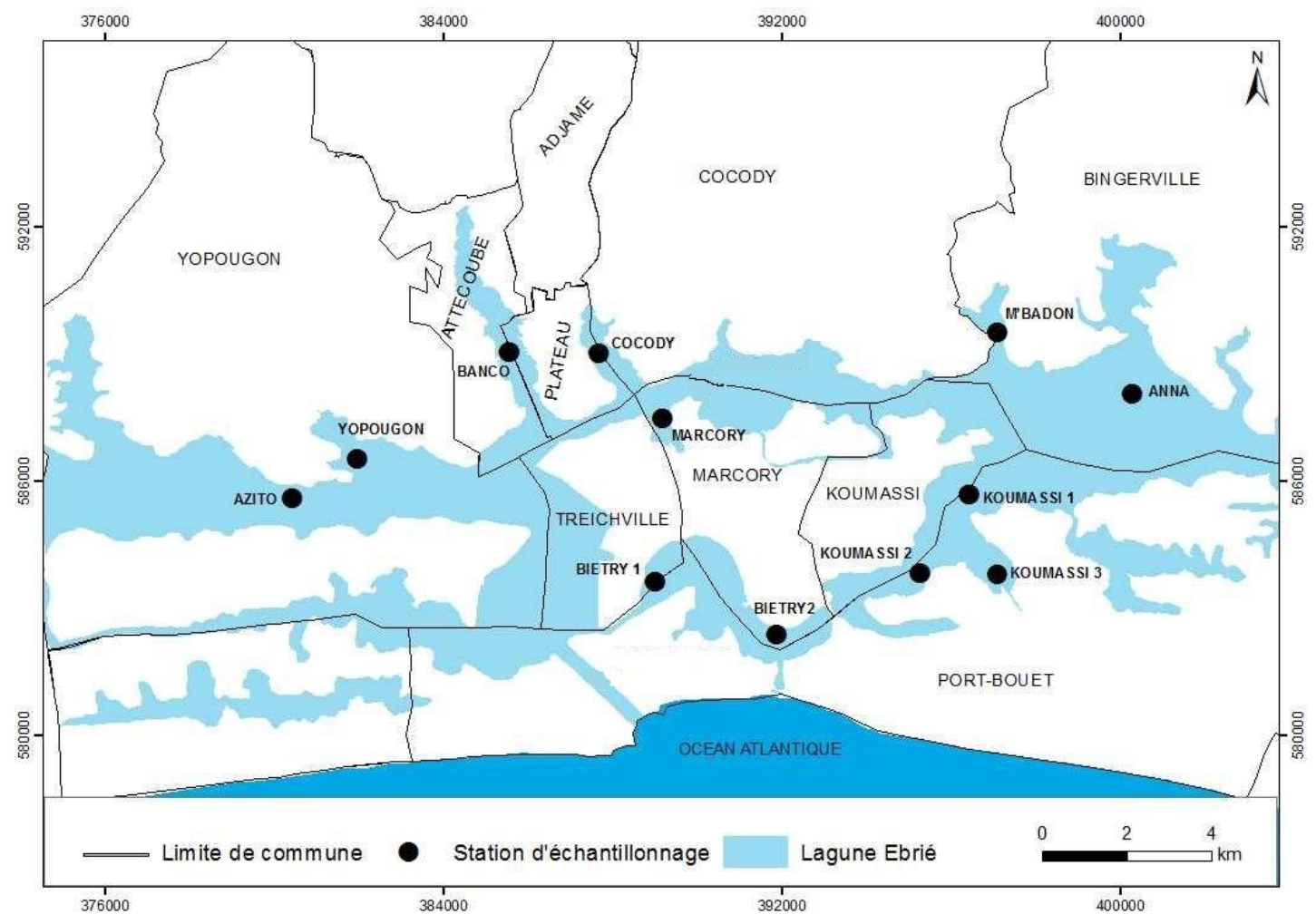

Figure 1: Location of sampling sites

Table I: Limits of the WFD status classes [17]

\begin{tabular}{|l|l|l|l|l|l|l|l|l|l|}
\hline \multicolumn{1}{|c|}{ Parameters } & Very Good & & Good & & Medium & & Médiocre & & Wrong \\
\hline Dissolved oxygen (mg/L) & & 8 & & 6 & & 4 & & 3 & \\
\hline Orthophosphate (mg/L) & & 0,1 & & 0,5 & & 1 & & 2 & \\
\hline Ammonium (mg/L) & & 0,1 & & 0,5 & & 2 & & 5 & \\
\hline Nitrite (mg/L) & & 0,1 & & 0,3 & & 0,5 & & 1 & \\
\hline Nitrate (mg/L) & & 10 & & 50 & & $*$ & & $*$ & \\
\hline
\end{tabular}

* current knowledge does not allow reliable thresholds to be set for this limit

\section{f) Determination of nutrient exceedance rate}

The richness of urban water in nutrients was estimated from the limit values proposed by Chapman [18] and Rodier et al.[16]. According to these authors, in order for a natural environment to be considered unpolluted, the content of these elements must be less than $0.02 \mathrm{mg} / \mathrm{L}$ and $0.01 \mathrm{mg} /$ $\mathrm{L}$ respectively for phosphate and for nitrite and at $1 \mathrm{mg} / \mathrm{L}$ and $0.1 \mathrm{mg} / \mathrm{L}$ respectively for nitrate and ammonium. The rate at which these limit values were exceeded was calculated as follows:

$$
\text { Exceeding rate }=\frac{\text { Number of measurements exceeding the limit value }}{\text { Total number of measurements }} \times 100
$$




\section{g) Statistical processing}

Spatial variability of physico-chemical parameters and nutrients was assessed using the Kruskal-Wallis test at $\mathrm{p}$ $<0.05$. The multiple comparison of the medians of the measurements as well as their ranking were carried out using the Mann-Whitney test at the 5\% level, whenever the Kruskal-Wallis test revealed significant differences. All statistical calculations and graphs were done using Statistica 7.1 software.

\section{Results and discussion}

\section{a) Results}

Spatial variation of physico-chemical parameters

Figure 2 describes the spatial evolution of temperature, $\mathrm{pH}$, salinity and dissolved oxygen in the waters of lagoon bays.
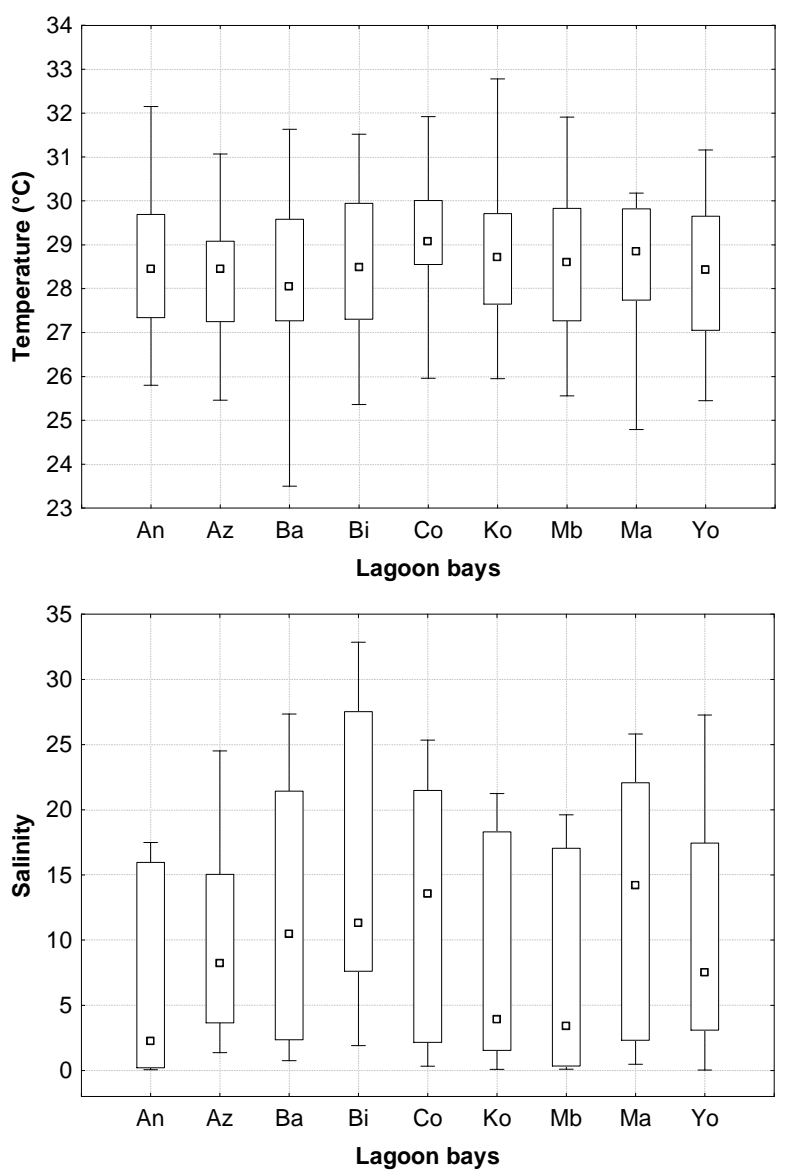

Comparison of the distribution of temperature and dissolved oxygen values shows that there is no significant difference between the bays ( $p>0.05$ ). On the contrary, the KruskalWallis test shows that there is a significant difference in the distribution of $\mathrm{pH}$ and salinity values ( $\mathrm{p}<0.05)$. The median $\mathrm{pH}$ values of Biétry and Koumassi bays are higher than those of Anna, Azito, Banco, Cocody, M'badon, Marcory and Yopougon bays. As for the median salinity values, they are higher in the bays of Banco, Biétry and Marcory than those of Anna, Koumassi and M'badon.
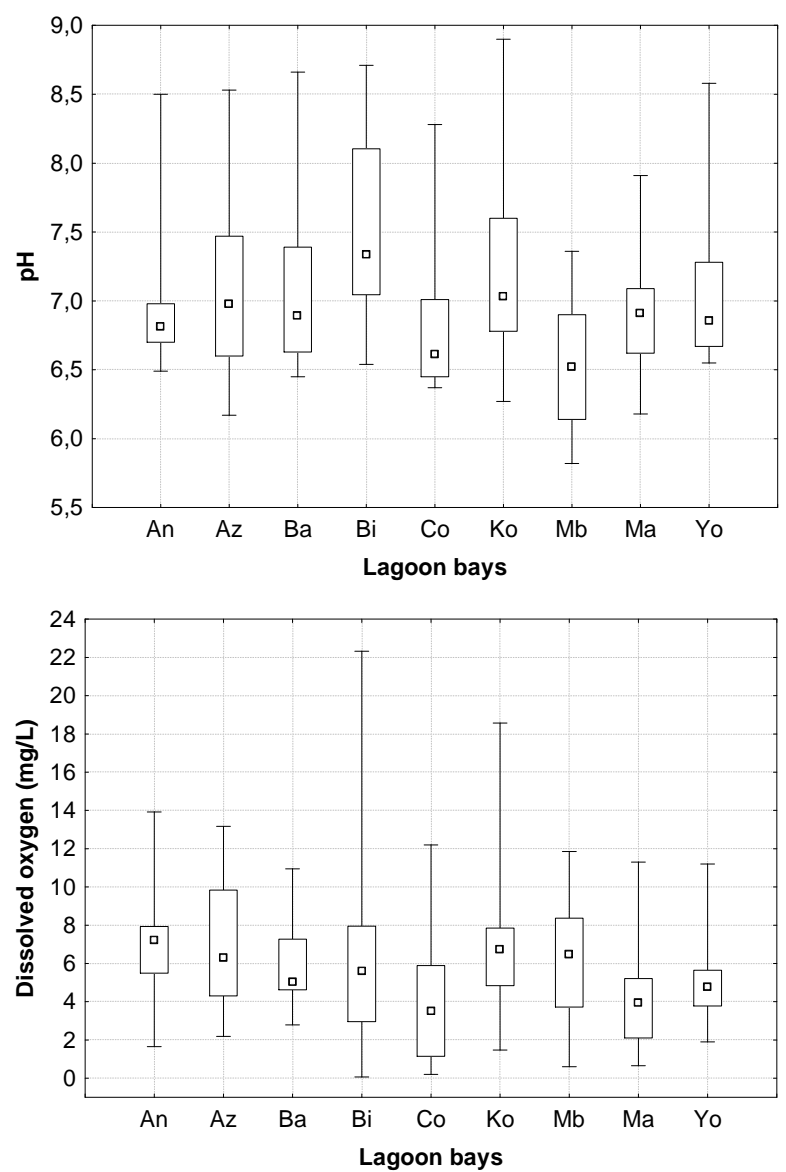

Figure 2: Spatial variation of physico-chemical parameters in lagoon bays.

\section{Spatial variation of nutrient salts}

The spatial profile of nutrient salts is shown in Figure 3. The Kruskal-Wallis test shows no difference ( $>>0.05)$ in the variation of nitrate and orthophosphate in bays. On the other hand, a significant difference $(p<0.05)$ is observed in the variation of nitrite and ammonium. The highest levels of nitrite are recorded in Banco, Biétry, Cocody, Koumassi, M'badon and Marcory bays and the lowest in Anna Bay. Median ammonium values are higher in Cocody, Yopougon and Marcory bays. The lowest values are recorded in the bays of Anna, Azito, Banco, Biétry, Koumassi and M'badon. 

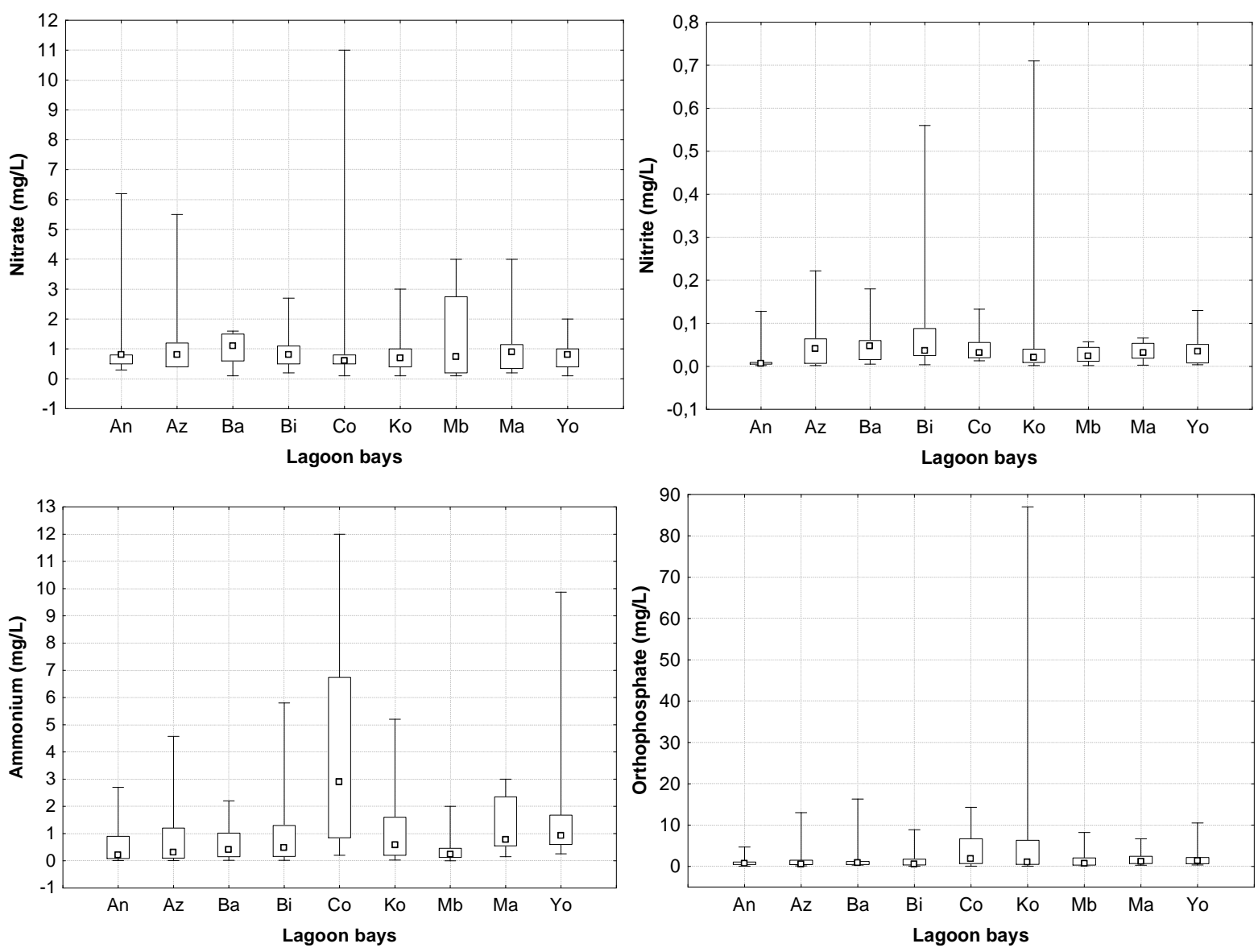

Figure 3: Spatial variation of nutrient salts in lagoon bays

\section{Abundance of nutrients in lagoon bays}

The rates of exceedance of the limit values are presented in Table II. In general, the analysis of this table shows the abundance of nutrients in the waters of the bays studied. Indeed, for ammonium, more than half of the measurements taken are above the limit value. The exceedance rate is between 69 and $100 \%$. It is the same for nitrite for which the rate is between 67 and 100\% except for Anna bay (20\%). For orthophosphate, all the measurements made in the bays exceed the limit value. On the other hand, less than $50 \%$ of the nitrate values in each bay exceed the limit value except in the bay of Banco (67\%).

\section{Ecological status of lagoon bays}

Table III shows the results of the physico-chemical analysis of the ecological status of the water in urban bays in the Ebrie lagoon. The quality of these waters varies according to the bay and according to the physico-chemical parameter.
Indeed, the dissolved oxygen content is good $\left(6<\left[\mathrm{O}_{2}\right]<8\right.$ $\mathrm{mg} / \mathrm{L})$ in the bay of Yopougon and very good $(8 \mathrm{mg} / \mathrm{L}$ $\left.<\left[\mathrm{O}_{2}\right]\right)$ in the other bays. The same is true for nitrite, the content of which is good $\left(0.1<\left[\mathrm{NO}_{2}^{-}\right]<0.3 \mathrm{mg} / \mathrm{L}\right)$ in the Banco, Biétry and Koumassi bays and very good $\left(\left[\mathrm{NO}_{2}{ }^{-}\right]<0\right.$, $1 \mathrm{mg} / \mathrm{L}$ ) in the other bays. The nitrate content is very good $\left(\left[\mathrm{NO}_{3}{ }^{-}\right]<10 \mathrm{mg} / \mathrm{L}\right.$ ) for all the bays studied. In contrast, the orthophosphate concentration varies from mediocre (1 $\left.<\left[\mathrm{PO}_{4}{ }^{3-}\right]<2 \mathrm{mg} / \mathrm{L}\right)$ in Anna bay to bad $\left(2 \mathrm{mg} / \mathrm{L}<\left[\mathrm{PO}_{4}{ }^{3-}\right]\right)$ in the other bays. The concentration of ammonium is medium $\left(0.5<\left[\mathrm{NH}_{4}{ }^{+}\right]<2 \mathrm{mg} / \mathrm{L}\right)$ in the bays of Banco and M'badon. It is bad $\left(5 \mathrm{mg} / \mathrm{L}<\left[\mathrm{NH}_{4}^{+}\right]\right)$in Cocody bays and mediocre $\left(2<\left[\mathrm{NH}_{4}^{+}\right]<5 \mathrm{mg} / \mathrm{L}\right)$ in the other bays. Very high levels of ammonium and orthophosphate are recorded in the bays of Cocody $(7.20 \mathrm{mg} / \mathrm{L}$ for ammonium and $11.80 \mathrm{mg} /$ $\mathrm{L}$ for orthophosphate), Marcory (3.00 mg / L for ammonium and $6.00 \mathrm{mg} / \mathrm{L}$ for orthophosphate) and Koumassi (2.70 mg / L for ammonium and $14.00 \mathrm{mg} / \mathrm{L}$ for orthophosphate).

Table II: Comparison of the nutrient content of bays water with limit values.

\begin{tabular}{|l|c|c|c|c|}
\hline Lagoon bays & Rate of Nitrate & Rate of Nitrite & Rate of Ammonium & Rate of Phosphate \\
\hline Anna & $22 \%$ & $20 \%$ & $69 \%$ & $100 \%$ \\
\hline Azito & $33 \%$ & $67 \%$ & $79 \%$ & $100 \%$ \\
\hline Banco & $67 \%$ & $93 \%$ & $79 \%$ & $100 \%$ \\
\hline Biétry & $33 \%$ & $88 \%$ & $83 \%$ & $100 \%$ \\
\hline Cocody & $22 \%$ & $100 \%$ & $100 \%$ & $100 \%$ \\
\hline Koumassi & $26 \%$ & $73 \%$ & $81 \%$ & $100 \%$ \\
\hline M'badon & $38 \%$ & $86 \%$ & $92 \%$ & $100 \%$ \\
\hline Marcory & $38 \%$ & $92 \%$ & $100 \%$ & $100 \%$ \\
\hline Yopougon & $33 \%$ & $71 \%$ & $100 \%$ & $100 \%$ \\
\hline
\end{tabular}


Table III: Results of the physico-chemical analysis of the ecological status of urban bays on the Ebrie lagoon

\begin{tabular}{|c|c|c|c|c|c|c|c|c|c|}
\hline ANNA & Very Good & & Good & & Medium & & Mediocre & & Bad \\
\hline Dissolved oxygen (mg/L) & $\mathbf{1 1 , 6 8}$ & 8 & & 6 & & 4 & & 3 & \\
\hline Orthophosphate (mg/L) & & 0,1 & & 0,5 & & 1 & $\mathbf{1 , 7 9}$ & 2 & \\
\hline Ammonium (mg/L) & & 0,1 & & 0,5 & & 2 & $\mathbf{2 , 7 0}$ & 5 & \\
\hline Nitrite (mg/L) & $\mathbf{0 , 0 2}$ & 0,1 & & 0,3 & & 0,5 & & 1 & \\
\hline Nitrate (mg/L) & $\mathbf{1 , 0 0}$ & 10 & & 50 & & $*$ & & $*$ & \\
\hline
\end{tabular}

\begin{tabular}{|l|c|c|c|c|c|c|c|c|c|}
\hline \multicolumn{1}{|c|}{ AZITO } & Very Good & & Good & & Medium & & Mediocre & & Bad \\
\hline Dissolved oxygen (mg/L) & $\mathbf{1 1 , 8 2}$ & 8 & & 6 & & 4 & & 3 & \\
\hline Orthophosphate (mg/L) & & 0,1 & & 0,5 & & 1 & & 2 & $\mathbf{2 , 8 0}$ \\
\hline Ammonium (mg/L) & & 0,1 & & 0,5 & & 2 & $\mathbf{2 , 5 0}$ & 5 & \\
\hline Nitrite (mg/L) & $\mathbf{0 , 0 1}$ & 0,1 & & 0,3 & & 0,5 & & 1 & \\
\hline Nitrate (mg/L) & $\mathbf{1 , 3 0}$ & 10 & & 50 & & $*$ & & $*$ & \\
\hline
\end{tabular}

\begin{tabular}{|c|c|c|c|c|c|c|c|c|c|}
\hline BANCO & Very Good & & Good & & Medium & & Mediocre & & Bad \\
\hline Dissolved oxygen (mg/L) & $\mathbf{1 0 , 7 5}$ & 8 & & 6 & & 4 & & 3 & \\
\hline Orthophosphate (mg/L) & & 0,1 & & 0,5 & & 1 & & 2 & $\mathbf{3 , 8 0}$ \\
\hline Ammonium (mg/L) & & 0,1 & & 0,5 & $\mathbf{1 , 6 0}$ & 2 & & 5 & \\
\hline Nitrite (mg/L) & & 0,1 & $\mathbf{0 , 1 5}$ & 0,3 & & 0,5 & & 1 & \\
\hline Nitrate (mg/L) & $\mathbf{1 , 5 0}$ & 10 & & 50 & & $*$ & & $*$ & \\
\hline
\end{tabular}

\begin{tabular}{|l|c|c|c|c|c|c|c|c|c|}
\hline \multicolumn{1}{|c|}{ BIETRY } & Very Good & & Good & & Medium & & Mediocre & & Bad \\
\hline Dissolved oxygen (mg/L) & $\mathbf{8 , 9 0}$ & 8 & & 6 & & 4 & & 3 & \\
\hline Orthophosphate (mg/L) & & 0,1 & & 0,5 & & 1 & & 2 & $\mathbf{3 , 5 2}$ \\
\hline Ammonium (mg/L) & & 0,1 & & 0,5 & & 2 & $\mathbf{2 , 1 7}$ & 5 & \\
\hline Nitrite (mg/L) & & 0,1 & $\mathbf{0 , 2 1}$ & 0,3 & & 0,5 & & 1 & \\
\hline Nitrate (mg/L) & $\mathbf{1 , 6 0}$ & 10 & & 50 & & $*$ & & $*$ & \\
\hline
\end{tabular}

\begin{tabular}{|l|c|c|c|c|c|c|c|c|c|}
\hline \multicolumn{1}{|c|}{ COCODY } & Very Good & & Good & & Medium & & Mediocre & & Bad \\
\hline Dissolved oxygen (mg/L) & $\mathbf{1 0 , 8 4}$ & 8 & & 6 & & 4 & & 3 & \\
\hline Orthophosphate (mg/L) & & 0,1 & & 0,5 & & 1 & & 2 & $\mathbf{1 1 , 8 0}$ \\
\hline Ammonium (mg/L) & & 0,1 & & 0,5 & & 2 & & 5 & $\mathbf{7 , 2 0}$ \\
\hline Nitrite $(\mathrm{mg} / \mathrm{L})$ & $\mathbf{0 , 0 6}$ & 0,1 & & 0,3 & & 0,5 & & 1 & \\
\hline Nitrate $(\mathrm{mg} / \mathrm{L})$ & $\mathbf{6 , 0 0}$ & 10 & & 50 & & $*$ & & $*$ & \\
\hline
\end{tabular}

\begin{tabular}{|l|c|c|c|c|c|c|c|c|c|}
\hline \multicolumn{1}{|c|}{ KOUMASSI } & Very Good & & Good & & Medium & & Mediocre & & Bad \\
\hline Dissolved oxygen (mg/L) & $\mathbf{1 0 , 3 5}$ & 8 & & 6 & & 4 & & 3 & \\
\hline Orthophosphate (mg/L) & & 0,1 & & 0,5 & & 1 & & 2 & $\mathbf{1 4 , 0 0}$ \\
\hline Ammonium (mg/L) & & 0,1 & & 0,5 & & 2 & $\mathbf{2 , 7 0}$ & 5 & \\
\hline Nitrite $(\mathrm{mg} / \mathrm{L})$ & & 0,1 & $\mathbf{0 , 1 2}$ & 0,3 & & 0,5 & & 1 & \\
\hline Nitrate (mg/L) & $\mathbf{1 , 4 0}$ & 10 & & 50 & & $*$ & & $*$ & \\
\hline
\end{tabular}

\begin{tabular}{|l|c|c|c|c|c|c|c|c|c|}
\hline \multicolumn{1}{|c|}{ M'BADON } & Very Good & & Good & & Medium & & Mediocre & & Bad \\
\hline Dissolved oxygen (mg/L) & $\mathbf{1 0 , 4 2}$ & 8 & & 6 & & 4 & & 3 & \\
\hline Orthophosphate (mg/L) & & 0,1 & & 0,5 & & 1 & & 2 & $\mathbf{6 , 2 0}$ \\
\hline Ammonium (mg/L) & & 0,1 & & 0,5 & $\mathbf{1 , 2 6}$ & 2 & & 5 & \\
\hline Nitrite (mg/L) & $\mathbf{0 , 0 5}$ & 0,1 & & 0,3 & & 0,5 & & 1 & \\
\hline Nitrate (mg/L) & $\mathbf{4 , 0 0}$ & 10 & & 50 & & $*$ & & $*$ & \\
\hline
\end{tabular}

\begin{tabular}{|l|c|c|c|c|c|c|c|c|c|}
\hline \multicolumn{1}{|c|}{ MARCORY } & Very Good & & Good & & Medium & & Mediocre & & Bad \\
\hline Dissolved oxygen (mg/L) & $\mathbf{1 0 , 1 5}$ & 8 & & 6 & & 4 & & 3 & \\
\hline Orthophosphate (mg/L) & & 0,1 & & 0,5 & & 1 & & 2 & $\mathbf{6 , 0 0}$ \\
\hline Ammonium (mg/L) & & 0,1 & & 0,5 & & 2 & $\mathbf{3 , 0 0}$ & 5 & \\
\hline Nitrite (mg/L) & $\mathbf{0 , 0 6}$ & 0,1 & & 0,3 & & 0,5 & & 1 & \\
\hline Nitrate (mg/L) & $\mathbf{1 , 2 0}$ & 10 & & 50 & & $*$ & & $*$ & \\
\hline
\end{tabular}

\begin{tabular}{|l|c|c|c|c|c|c|c|c|c|}
\hline \multicolumn{1}{|c|}{ YOPOUGON } & Very Good & & Good & & Medium & & Mediocre & & Bad \\
\hline Dissolved oxygen (mg/L) & & 8 & $\mathbf{7 , 8 8}$ & 6 & & 4 & & 3 & \\
\hline Orthophosphate (mg/L) & & 0,1 & & 0,5 & & 1 & & 2 & $\mathbf{3 , 0 0}$ \\
\hline Ammonium (mg/L) & & 0,1 & & 0,5 & & 2 & $\mathbf{3 , 0 0}$ & 5 & \\
\hline Nitrite $(\mathrm{mg} / \mathrm{L})$ & $\mathbf{0 , 0 9}$ & 0,1 & & 0,3 & & 0,5 & & 1 & \\
\hline Nitrate $(\mathrm{mg} / \mathrm{L})$ & $\mathbf{1 , 3 0}$ & 10 & & 50 & & $*$ & & $*$ & \\
\hline
\end{tabular}




\section{b) Discussion}

The spatial variability of temperature values is low in lagoon waters. No significant difference was observed in the variation of temperature as well as in the variation of dissolved oxygen. According to Durand and Skubich [19], the variability of dissolved oxygen in surface water is relatively high, around $3.25 \mathrm{mg} / \mathrm{L}$. However, the differences apparently observed are not necessarily significant. For the $\mathrm{pH}$, the observed spatial variation could be explained by the influence of border environments. Indeed, the high values could be due to the preponderance of oceanic waters which are basic and the low values to the contribution of continental waters, which are rather acidic [19-20]. All this coupled with the strong photosynthetic activity of phytoplankton and the formation of nitrogenous organic compounds [21]. Thus, the low $\mathrm{pH}$ values recorded in bays such as M'badon, Anna, Cocody are due to the strong influence of continental waters. These results are similar to those found by Soro et al. [22]. Bays which register frequent inflows of oceanic waters show high values of salinity. This is the case with the bays of Biétry, Banco and Marcory. In contrast, the bays (Anna, M'badon and Koumassi) that is furthest away record low salinity values due to the influence of continental waters.

According to Pagès et al. [23] and Dufour and Lemasson [24], nutrient concentrations in surface water vary regularly under the influence of surrounding environments. However, the variations of nitrate and orthophosphate in the waters studied do not show any significant difference. This is not the case for nitrite and ammonium. In the case of ammonium, for example, the high concentrations obtained in Cocody, Marcory and Yopougon bays may be linked to the accelerated urbanization and the demographic and industrial growth of their watersheds [8].

The nitrate exceedance rates in the bay waters are less than $50 \%$ except in Banco Bay (67\%). This result therefore does not indicate a strong fertilizer contamination in most bays. With the exception of nitrate, the high levels of phosphorus and nitrogen compounds in the waters studied testify to their significant enrichment in nutrient salts. The latter would come from the decomposition of organic matter from the watershed as underlined by Kouamé et al.[25]. The studied area is subject to significant land and urban inputs, which justifies the high exceedance rates observed.

The physico-chemical analysis of the ecological status of urban bays shows optimal dissolved oxygen, nitrate and nitrite levels for aquatic life. In this study, orthophosphate and ammonium were found to be major causes of the degradation of the ecological status of the waters of all the bays, although the phosphate was in a greater proportion than that of the ammonium. This is in connection with the urban impacts responsible for raw domestic wastewater inputs which downgrade the urban area in mediocre to bad and medium to bad quality respectively for orthophosphate and ammonium. The analysis of ammonium and orthophosphate inputs in the water shows a clear increase in the lagoon environment, particularly in the bays of Cocody, Marcory and Koumassi. This can probably be explained by the proximity of the sources of discharge or by the hydrodynamics of these bays [26] but also by the high human activity and the sanitation problems in these bays. The current ecological status of the urban waters of the Ebrie lagoon is unable to promote optimal aquatic life for flora and fauna on the basis of ammonium and orthophosphate.

\section{Conclusion}

This study showed that the physico-chemical characteristics of the waters of the bays of the city of Abidjan vary according to oceanic and continental inputs. The bays that receive industrial and urban waste are very rich in nitrogen and phosphorus compounds. The physico-chemical analysis of the ecological status of these bays has shown the degradation of this state by ammonium and orthophosphate. Overall, the waters studied are not able to promote optimal aquatic life for fauna and flora and to allow biological balances in the environment. These waters therefore present a worrying ecological status.

\section{References}

[1] Villanueva M. C. S., 2004. Biodiversité et relations trophiques dans quelques milieux estuariens et lagunaires de l'Afrique de l'ouest: Adaptations aux pressions environnementales. Thèse de Doctorat, Institut National Polytechnique de Toulouse, $248 \mathrm{p}$.

[2] Kouakou S. K., Aka M. K., Amma A. A., Dongui B. K. \& Gnakri D., 2008. Variations saisonnières des paramètres abiotiques des eaux d'une lagune tropicale: La lagune de Grand-Lahou, Côte D'Ivoire. European Journal of Scientific Research Vol.21 No.3 (2008) : 376-393.

[3] Marchand J. \& Martin L., 1985. Détermination de la pollution chimique (Hydrocarbures, Organochlorés, métaux) dans la lagune d'Abidjan (Côte d'Ivoire) par l'étude des Sédiments. Océanogr. Trop. 20 (1) : 25-39.

[4] Kouadio \& Trefry J. H., 1987. Sediment trace metals contamination in Ivory Coast, West Africa. Water air Soil Pollut : 54-145

[5] Kouamé K. V., 2012. Caractérisation physicochimique et impacts écotoxicologiques des effluents industriels dans la lagune Ebrié. Thèse de doctorat de Sciences et Gestion de l'environnement, Université Nangui Abrogoua, ${ }^{\circ} 115,180 \mathrm{p}$.

[6] Dufour P. \& Slépoukha M., 1975. L'oxygène dissous en lagune Ebrié : influence de l'hydroclimat et des pollutions. Documents scientifiques de Centre de Recherches Océanographiques d'Abidjan, 6 (2) : 75118.

[7] Inza B., Soro B.M, Etchian A.O., Trokourey A., Bokra Y., 2009. Caractérisation physicochimique des eaux et des sédiments de surface de la baie des Milliardaires, lagune Ebrié, Côte d'Ivoire. Rev. Ivoir. Sci. Tech., 13 : 139-154.

[8] Yao K. M., Métongo B. S., Trokourey A. \& Bokra Y., 2009. La pollution des eaux de la zone urbaine d'une lagune tropicale par les matières oxydables (lagune Ebrié, Côte d'Ivoire). Int. J. Biol. Chem. Sci.,3 (4), 755-770.

[9] Soro B.M., 2013. Etude de la qualité des eaux et sédiments dans le plan d'eau du domaine du Port d'Abidjan. Rapport final. 57 p. 
[10] Tuo A. D., Soro M. B., Trokourey A. \& Bokra Y., 2015. Evidence of organic pollution observed in Ebrie lagoon around Abidjan City (Côte d'Ivoire). American. Int. J. Res. Formal. Applied. Nat. Sci., 15- 135 : pp 4045.

[11] Dufour P., 1982 : Les frontières naturelles et humaines du système lagunaire Ebrié. Hydrobiologia, 94 : 105120.

[12] INS, 2014. Recensement Général de la Population et de l'Habitat en Côte d'Ivoire. Résultats globaux. Secrétariat Technique Permanent du Comité Technique du RGPH, $26 \mathrm{p}$.

[13] Ané A. A., 2017. Qualité environnementale d'un estuaire à pression anthropique et à forçages naturels saisonniers en lagune Ebrié (Sud - Est de la Côte D'Ivoire). Thèse de Doctorat d'Etat, Université de Cocody, $297 \mathrm{p}$.

[14] Dufour P., Kouassi A. M. \& Lanusse A., 1994. Les pollutions. In: Environnement et Ressources aquatiques de Côte d'Ivoire. Les milieux lagunaires. Ed. ORSTOM : 309-333.

[15] Afnor, 2001. Qualité de l'eau, Eléments majeurs-autres éléments et composés minéraux. Aubenas Ardèche, 6e Edition, $635 \mathrm{p}$.

[16] Rodier J., Legube B., Merlet N., 2009. L'analyse de l'eau. 9è édition. Dunod, Paris. 1579 p.

[17] Observatoire de l'eau, 2009. Suivi des réseaux de surveillance des cours d'eau de Seine-et-Marne. Conseil général de Seine et Marne. $71 \mathrm{p}$.

[18] Chapman D., 1996. Water Quality Assessment: A guide to the use of biota, sediments and water in environmental monitoring. 2nd édition, E\&FN Spon, London, $651 \mathrm{p}$.

[19] Durand J. R. \& Skubich M., 1982. Les lagunes ivoiriennes. Aquaculture, 27 : 211-250.

[20] Arfi R. \& Guiral D., 1994. Un écosystème estuarien eutrophe: la baie de Biétri. In Environnement et ressources aquatiques de Côte d'Ivoire. Les milieux lagunaires, Edit. Orstom : 335-363

[21] Yao K. M., 2009. Contribution à l'étude des paramètres physico-chimiques des eaux de la lagune Ebrié dans la zone d'Abidjan (Côte d'Ivoire). Thèse de Doctorat, Université de Cocody, 182p.

[22] Soro G., Soro B. M., Soro N., Ahoussi E. K., Kouamé F. K., Zade S. \& Soro T., 2009. Métaux lourds $(\mathrm{Cu}, \mathrm{Cr}$, $\mathrm{Mn}$ et $\mathrm{Zn}$ ) dans les sédiments de surface d'une lagune tropicale africaine ; cas de la lagune Ebrié (Côte d'Ivoire). Int. Jour. Biol. Chem. Sci. 3(6) : 1408-1427.

[23] Pagès, J., Dufour P. et Lemasson L., 1979. Pollution de la zone urbaine de la lagune Ebrié (Côte d'Ivoire). Doc. Sc. Cent. Rech. Océanogr. Abidjan, 11 : 79-107.

[24] Dufour P. \& Lemasson L., 1985. Le régime nutritif de la lagune tropicale Ebrié (Côte-d'lvoire). Océanogr. Trop. 20 (1): 41-69.

[25] Kouamé K. V., Yapo O. B., Mambo V., Seka A., Tidou A. S. \& Houenou P., 2009. Physicochemical characterization of the waters of the coastal rivers and the lagoonal system of Côte d'Ivoire. J. Appl. Sci., 9 (8) : 1517-1523.

[26] Ciapol, 2017. Etude de faisabilité de la dépollution des baies lagunaires d'Abidjan. Côte d'Ivoire - Phase 1. Diagnostic de l'Etat Actuel. 155 p. 